\title{
The Role of Surgery in the Treatment of Patients with Obstrutive Sleep Apnea
}

\author{
Douglas Rangel Goulart ${ }^{1 *}$ and Eder Alberto Sigua-Rodriguez ${ }^{2}$ \\ ${ }^{1}$ Oral and Maxillofacial Surgery, Centro Universitário Euro-Americano - UNIEURO, Brazil \\ ${ }^{2}$ Oral and Maxillofacial Surgeon, Private practice, Colombia
}

Submission: April 13, 2017; Published: April 19, 2017

*Corresponding author: Douglas Rangel Goulart, Dental School - Department of Oral and Maxillofacial Surgery, UNIEURO, Brasília - Brazil, Avenida das Nações, Trecho 0, Conjunto 05, Tel: +55 61 35533797; douglas.goulart@uieuro.com.br /douglasrgoulart@gmal.com

\begin{abstract}
Obstructive sleep apnea is a common sleep-related breathing disorderresulting from repetitive narrowing and collapsing of the upper airway. The treatment of this condition require a multidisciplinary team. Surgery for maxilomandibular advancement seems to be the most effective surgical treatment for obstructive sleep apnea. The purpose of this paper is to provide an overview of the surgical treatment of obstructive sleep apnea.
\end{abstract}

Keywords: Jaw surgery; Obstructive sleep apneas; Orthognathic surgery; Respiration disorders

\section{Introduction}

Obstructive sleep apnea is a common sleep-related breathing disorder of major public health importance. However, the treatment remains challenging. The current gold standard, particularly for moderate to severe cases, is continuous positive airway pressure, but it is often suboptimal because patients dislike it so do not tolerate it [1]. Thus, many surgical techniques have been reported initially as an alternative treatment to these patients. The ultimate goal of surgical treatment for obstructive sleep apnea is to improve symptoms and eliminate disease morbidity and mortality.

\section{Surgical treatment for obstructive sleep apnea}

Uvulopalatopharyngoplasty has long remained the most common obstructive sleep apnea surgery but suffers from technical failure. Transpalatal advancement pharyngoplasty described by Woodson [2] alters the retropalatal airway by advancing the palate forward [2]. Compared to

uvulopalatopharyngoplasty, significant increases in crosssectional area and decrease in pharyngeal collapsibility have been measured [3]. This technique include the excision of posterior portion of maxilla and palatine bone, and advancing the plate into the defect achieve advancement [2].

Maxilomandibular advancement is the most effective surgical treatment for obstructive sleep apnea. This treatment traditionally consists of bilateral sagittal split osteotomies of the mandible, and
Le Fort I osteotomy of the maxilla. The aim of this advancement is increase the caliper of upper airway, thereby preventing its collapse during sleep. The results are linked to results in surrounding structures, such as facial skeleton, soft palate, tongue and hyoid [1].

Maxilomandibular advancement was used as a primary intervention by more investigators in the past few years than had been done in the past. Obstructive sleep apnea patients with skeletal deficiency could benefit from this treatment as a primary surgical intervention [4]. The classic Riley-Powell maxilomandibular advancement technique is the singles splint technique where the only a final splint is used for the occlusion. No model surgery is done with an intermediate splint for maxillomandibular movements. This technique used Le Fort I osteotomy and sometimes the counterclockwise rotation of maxilla to create adequate pharyngeal tension [5]. Currently, the treatment could be more predictable with the development of virtual surgical planning using cone-beam computed tomography images and accompanying software. It is possible to simulate the movement of jaws and predict the enlargement of airway in volume. The occlusal splints could be designed virtually by an engineer and surgeon working together. Thus, a 3D printing device could generate occlusal splints. Virtual surgical planning is seems to be a feasible tool used to predicting surgical outcomes measures in maxilomandibular advancement surgery for patients with obstructive sleep apnea [6]. Nevertheless, there is no 
consensus regarding the impact of some variables evaluated in these studies like the difference between the scanning position of the patient and the sleeping position, the variation between studies regarding the determination of anatomical limits airway, the most appropriate moment to make follow-up assessments and the lack of inter and intra-examiner reliability [7].

Maxilomandibular advancement is an effective operation for the treatment of obstructive sleep apnea, as it not only enlarges the upper airway in the anteroposterior and lateral dimensions, but also raises the hyoid [1]. Over the past five years, hyoid suspension have only been used in rare occasions because maxilomandibular advancement (with or without genioglossus advancements) have yielded good results. Overall, this treatment complications are low [5]. Bimaxillary osteotomies are routinely performed to correct dentofacial deformities, the technique used was similar to treat obstructive sleep apnea patients. Thus, similar complications can be anticipated. The common complications includes hyperesthesia of the lower lip, local infection, malocclusion, temporomandibular joint disorders, bleeding, unfavorable split of sagittal ramus osteotomies, non-union, oro-antral communication and fixation failure [8].

Obstructive Sleep Apnea could present multiples areas of obstruction, transpalatal advancement pharyngoplasty alters only a portion of the airway [9]. The advantage of maxilomandibular advancement compared to others obstructive sleep apnea procedures is the possibility of expanding the pharynx from the level of soft palate to the base of the tongue. Furthermore, the results of surgery based on skeletal advancement appear to be much more stable than interventions in the soft tissue [4]. The modification of the upper airway volume is the main objective of measurement of most of studies because of the relationship of the upper airways with obstructive sleep apnea. However, other clinical features could elucidate the outcomes of surgery, like body mass index and apnea index [7].

All investigators agree that minimal maxilla advancement of $10 \mathrm{~mm}$ is required for successful treatment of obstructive sleep apnea. Adverse esthetic effects could be anticipated in conjunction with this degree of skeletal modification [4]. Some authors have tried to modify surgical techniques to achieve greater advancement with minimal adverse esthetic effects. Goh et al. [10] performed extraction of bicuspid intraoperatively and remove a segment of maxilla, this procedure involves anterior segmental surgeries to posterior setback of alveolar process during maxilomandibular advancement. This technique is complex and increases the risk of maxilla and mandibular segment necrosis [10].

\section{Conclusion}

The relation between improvement of apnea and maxilomandibular advancement has been related by several studies. The bimaxillary advancement surgery can effectively increase the volume of the upper airway;however, it is necessary an enforcement to strengthen and spread these results. Despite of benefits of surgery, the treatment of obstructive sleep apnea is multidisciplinary and require a precise indication for surgery.

\section{Conflict of Interest}

The authors declare that there is no conflict of interest related to this study.

\section{References}

1. Hsieh YJ, Liao YF (2013) Effects of maxillomandibular advancement on the upper airway and surrounding structures in patients with obstructive sleep apnoea: A systematic review. Br J Oral Maxillofac Surg 51(8): 834-840.

2. Woodson BT, Toohill RJ (1993) Transpalatal advancement pharyngoplasty for obstructive sleep apnea. Laryngoscope 103(3): 269-276.

3. Woodson BT, Robinson S, Lim HJ (2005) Transpalatal advancement pharyngoplasty outcomes compared with uvulopalatopharygoplasty. Otolaryngol - Head Neck Surg 133(2): 211-217.

4. Pirklbauer K, Russmueller G, Stiebellehner L, Nell C, Sinko K, et al. (2011) Maxillomandibular advancement for treatment of obstructive sleep apnea syndrome: A systematic review. J Oral Maxillofac Surg 69(6): e165-e176.

5. Camacho M, Yung S, Certal V, Capasso R, Powell NB, Riley RW (2015) Large maxillomandibular advancements for obstructive sleep apnea : An operative technique evolved over 30 years J Craniomaxillofac Surg 43(7): 1113-1118.

6. Barrera JE (2016) Skeletal Surgery for Obstructive Sleep Apnea. Otolaryngol Clin North Am 49(6): 1433-1447.

7. Stefan M, Irlan O, Freires A, Rosa HD, Souza F De, et al. (2017) Efficiency of bimaxillary advancement surgery in increasing the volume of the upper airways : a systematic review of observational studies and metaanalysis. Eur Arch Otorhinolaryngol 274(1): 35-44.

8. Robl MT, Farrell BB, Tucker MR (2014) Complications in Orthognathic Surgery A Report of 1000 Cases. Oral Maxillofac Surg Clin NA. 26(4): 599-609.

9. Woodson BT (2007) Transpalatal advancement pharyngoplasty. Rhinol Sleep Apnea Surg Tech 339-346.

10. Goh YH, Lim KA (2003) Modified maxillomandibular advancement for the treatment of obstructive sleep apnea: a preliminary report. Laryngoscope 113(9): 1577-1582. 
This work is licensed under Creative Commons Attribution 4.0 Licens DOI: 10.19080/ADOH.2017.04.555645
Your next submission with Juniper Publishers will reach you the below assets

- Quality Editorial service

- Swift Peer Review

- Reprints availability

- E-prints Service

- Manuscript Podcast for convenient understanding

- Global attainment for your research

- Manuscript accessibility in different formats ( Pdf, E-pub, Full Text, Audio)

- Unceasing customer service

Track the below URL for one-step submission https://juniperpublishers.com/online-submission.php 